\title{
Otantik Liderlik İle Örgütsel Bağlılık Arasında Psikolojik Sermayenin Aracılık Rolü: Bingöl Üniversitesi Örneği
}

\author{
DOI: 10.26466/opus. 501018 \\ * \\ Tuba Büyükbeşe*- $\underline{\text { Sinan CCavușoğlu }}^{* *}$ - Olcay Okun ${ }^{* * *}$ \\ * Doç.Dr., Hasan Kalyoncu Üniversitesi, İ̈BF, İşletme Bölümü, 27000, Gaziantep / Türkiye \\ E-Posta: tuba.buyukbese@hku.edu.tr ORCID: 0000-0003-4174-9870 \\ ** Öğr. Gör., Bingöl Üniversitesi, Sosyal Bilimler MYO, Yönetim ve Org.Böl. Bingöl/Türkiye \\ E-Posta: sinankys42@gmail.com \\ ORCID: 0000-0002-7096-5794 \\ *** Dr., Milli Savunma Bakanlığı, 65000, Van/Türkiye \\ E-Posta: olcayokun@yahoo.com.tr \\ ORCID: 0000-0003-2915-2334
}

Öz

Bu çalışmanın amacı, otantik liderlik ile örgütsel bağlllık arasındaki ilişkide psikolojik sermayenin aracılık rolünü belirlemektir. Araştırmanın örneklemini Bingöl Üniversitesinde görev yapan 295 akademik ve idari personel oluşturmuştur. Kolayda örneklem yönteminin kullanıldığ toplama aracı olarak anket kullanılmıştır. Ankette otantik liderlik, psikolojik sermaye ve örgütsel bağlllık değişkenlerini ölçmeye yönelik ifadeler ve demografik özelliklere ilişkin sorulara yer verilmiştir. Toplanan veriler SPSS ve AMOS programlarıla analiz edilmiştir. Konuya ilişkin kullanılan ölçeklerin geçerlilik ve güvenilirliği test edilmiş ve doğrulayıcı faktör analizi uygulanmıştır. Hipotezler korelasyon ve regresyon testi ile incelenmiş olup Sobel testi yapılarak sağlaması uygulanmış, elde edilen bulgular bu kapsamda yorumlanmıştır. Elde edilen bulgular örgütsel bağlılığın artmasında, otantik liderlik ve psikolojik sermayenin önemli rollerinin olduğunu göstermiştir. Ayrıca psikolojik sermayenin (öz yeterliliğin) otantik liderliğin, örgütsel bağhllık üzerindeki etkisinde kısmi aracı rolü olduğ $u$ tespit edilmiştir. Diğer taraftan psikolojik sermayenin iyimserlik, psikolojik dayanıklllık ve umut alt boyutlarmın otantik liderliğin ile örgütsel bağlllık arasında aracılık etkisi tespit edilmemiştir.

Anahtar Kelimeler: Otantik liderlik, Örgütsel bağlllık, Psikolojik sermaye 


\title{
The Mediation Effect of Psychological Capital Between Authentic Leadership and Organizational Commitment: The Case of Bingöl University
}

\begin{abstract}
The purpose of this study is to determine the mediating role of psychological capital in relation to authentic leadership and organizational commitment. The research sample was composed of 295 academic and administrative staff working at Bingöl University. In this study convenience sampling method and questionnaire was used as data collection tool. The questionnaire included authentic leadership, psychological capital and organizational commitment questions to measure variables and demographic characteristics. The collected data were analyzed with SPSS and AMOS programs. The validity and reliability of the scales used in this study were tested and confirmatory factor analysis was applied. The hypotheses were examined by correlation and regression test and Sobel test was applied and the obtained findings were interpreted in this context. Findings have shown that in increasing organizational commitment, there are important roles of authentic leadership and psychological capital. It has also been found that the authentic leadership of psychological capital (self-efficiency) has a partial mediator role in the effect on organizational commitment. On the other hand, the mediation effect of the optimism, psychological resilience and hope sub-dimensions of the psychological capital between the authentic leadership and the organizational commitment has not been demonstrated.
\end{abstract}

Keywords: Authentic leadership, Organizational commitment, Psychological capital 


\section{Giriş}

Son y1llarda yaşanan ekonomik, politik ve teknolojik gelişmeler işletmelerin, şeffaf ve etik yönetim anlayışı benimseyen, organizasyonun ve kendi değerlerinin farkında olan, liderlere olan ihtiyacını artırmıştır. Yönetim araştırmacıları, kısa vadede sadece çalışanlarını etkilemekle kalmayıp, diğer paydaşların değerlerini de önemseyerek onlara liderlik eden, bir vizyon yaratarak, rekabet avantajı sağlayan liderleri nasıl seçeceklerini ve geliştireceklerini belirlemek için çalışmalar yapmaktadır (Smith vd., 2008, s. 227).

Günümüzün modern liderlik tarzlarından otantik liderlik bu bağlamda öne çıkmaktadır. Otantik liderler, çalışanlarına yön verip, onların çalışmalarına ve yaşamlarına anlam vermelerine yardımcı olurlar (Gardner vd., 2005). Otantik liderler, değerleri, inançları ve görüşleri doğrultusunda, şeffaf, ilkeli, dürüst ve gerçek ilişkiler kurarlar (Gardner vd., 2005; Ilies vd., 2005, Walumbwa vd., 2008; Kernis, 2003). Bu durum işletmelerin amaç ve hedeflerine daha hızlı ulaşmalarını sağlayacaktır.

Örgütsel bağlılık, organizasyonda çalışanların hedeflerine ve değerlerine duyduğu sevgi ve sadakatin yanı sıra organizasyona tamamen kendi iyiliği için bir taraftarlık ve duygusal bağlılık olarak düşünülmektedir. Ayrıca işletmelerin etkinliği ve sürekliliği açısından örgütsel bağl1lık önemli ve güçlü bir kabuldür (Buchanan, 1974, s. 533).

Psikolojik sermaye, otantik liderlik gelişiminin öncüsü olarak kabul edilmektedir (Luthans ve Avolio, 2003). Çalışanların psikolojik sermayesinin gelişiminin, otantik liderlik tarzının ana bileşenlerinden olduğu öngörülmektedir (Luthans vd., 2007b).

Yönetim araştırmalarında, çalışanların örgütlerine olan bağlılıkları çeşitli faktörler altında değişkenlik gösterdiğinden, bu faktörlerin incelenmesi önemli bir araştırma sorusu olarak değerlendirilmektedir (Meyer vd., 1998). Yazında uygulanan liderlik tarzının örgütsel bağlılık üzerindeki pozitif etkisini gösteren çalışmalar mevcuttur (Kernis, 2003; Avolio vd., 2004; Gardner ve Schermerhorn, 2004; Walumbwa vd., 2008; Yaşbay, 2011). Otantik liderlik tarzı bir çok araştırmacı tarafından çalışılmış ve örgütsel bağlılığı olumlu yönde etkilediği belirlenmiştir (Luthans ve Avolio, 2003; Pittinsky ve Tyson, 2005; Shamir ve Eilam, 2005; Gardner vd., 2005; Bhindi vd., 2008, Walumbwa vd., 2008). 
Yazında otantik liderlik ve psikolojik sermaye arasındaki ilişkiyi inceleyen araştırmalar mevcuttur (Avolio vd., 2004; Tugade vd., 2004; Gardner vd., 2005; Norman vd., 2005; Ilies vd., 2005; Hoogh ve Den Hartog, 2008). Söz konusu çalışmalar genel olarak otantik liderliğin psikolojik sermayeyi ve pozitif duyguları teşvik ettiğini öne sürmektedir (Rego vd., 2012). Ampirik çalışmalar ile ortaya koyulan bu bilgiler ışığında işletmelerin, çalışanların örgütsel bağlılığını sağlayacak yolu bulmaları için liderliğe ve liderlik rolüne yöneldikleri görülmektedir (Luthans ve Avolio, 2003). Bu çalışmanın amacı, otantik liderlik, örgütsel bağlllık ve psikolojik sermaye değişkenleri arasındaki ilişkiyi ve otantik liderlikle örgütsel bağlllık arasındaki ilişkide psikolojik sermayenin aracılık rolünün olup olmadığını belirlemektir. Bu kapsamda öncelikle otantik liderlik, örgütsel bağlllık ve psikolojik sermaye ile ilgili teorik bilgiye yer verilmiştir.

Beklentilerin sürekli değişim gösterdiği küreselleşme sürecinde, liderliğin gelişimi de değişime uğramış ve ortaya çıkan modern liderlik kuramlarından biri de otantik liderlik olmuştur (Yaşbay, 2011, s. 33). Günümüzde liderlik ile ilgili birçok tanım yapılmaktadır. Genel anlamda liderlik, amaçları gerçekleştirmek için kişinin başkalarının faaliyetlerini etkilemesi ve yönlendirmesi olarak tanımlanabilir (Ertürk, 2009, s. 151). Otantik liderlik teorisi, kavramsal gelişimin ilk aşamalarında olmasına rağmen, otantiklik yapısının psikoloji ve felsefede derin kökleri vardır. Otantiklik kavramı Yunan felsefesinden psikolojiye aktarılmıştır ve 1980'li yıllar içerisinde bu kavram daha çok kullanılmaya başlamıştır (Walumbwa vd., 2008).

Pittinsky ve Tyson (2005) otantik liderliğin tanımının çok açık olmadığını ve yapılan çalışmalarda bunun net bir şekilde belirtilmediğini vurgulamışlardır. Bhindi vd. (2008, s. 3) otantik liderliği, yakın akrabalık geleneğine dayanan bir kök yapı olarak değerlendirmiştir. Bhindi ve Duignan (1997), liderliğin, ahlaki, samimi, gerçek ve güvenilir olduğu taktirde ancak otantik olabileceğini savunmuşlardır. Luthans ve Avolio (2003, s. 243) otantik olmanın her lider için gerekli bir ölçüt olduğunu belirtmişlerdir. Avolio vd., (2004, s. 4) otantik liderleri, düşünce ve davranışlarının başkaları tarafından fark edildiği, çevresindekilerin bakış açılarını, güçlü ve zayıf yönlerini, değerlerini ve bilgilerini bilen kişiler olarak tanımlamışlardır. Shamir ve Eilam (2005, s. 399) otantik lideri; 
kendi benlik kavramının merkezi bir unsuru olan, çözümlemeyi veya beklentilerini anlamayı başarmış, kendi içinde uyumu sağlayan ve kendilerini ifade etme yönünde davranış gösteren kişiler olarak tanımlamışlardır. Gardner vd. (2005) otantik liderliğin bu çeşitli bakış açılarını ve tanımlarını bütünleştirmeye çalışmış ve otantik liderliğin geliştirilmesine yönelik bir model önermişlerdir. Bu modelde otantik liderliğin unsurlarını öz farkındalık, dengeli değerlendirme, otantik davranış ve ilişkilerde şeffaflık olarak belirtmişlerdir. Ilies vd. (2005) yapmış oldukları çalışmada ise otantik liderliğin unsurlarını öz farkındalık, tarafsızlık, otantik davranış/eylem ve ilişkisel yönelim olarak belirlemişlerdir. Sexton (2007) ise otantik liderlik konusunda bir fikir birliğinin olmadığını ve yapılan çalışmalar sonucunda otantik liderlik unsurlarının öz farkındalık, öz düzenleme ve gelişim, pozitif ahlak anlayışı, ilişkilerde şeffaflık ve pozitif psikolojik sermaye olarak 6 gruba ayrıldığını belirtmiştir (Coşar, 2011, s. 60). Walumbwa vd. (2008) otantik liderliğin unsurlarını;

- Öz farkındalık,

- Bilgiyi dengeli değerlendirme,

- İçselleştirilmiş ahlak anlayışı,

- İlişkilerde şeffaflık olarak ele almıştır.

Ilies vd. (2005, s. 377) otantikliğin bir bileşeni olan öz farkındalığı, kişinin, kişisel özelliklerine, değerlerine, amaçlarına, duygularına ve bilişlerine karşı farkındalığını ve güveni ifade eden bir unsur olarak belirtmiştir. May vd. (2003, s. 248), kendine güvenmenin ve kendine sadık kalmanın, otantik liderlik için vazgeçilmez özellikler olduğunu savunmuşlardır. Avolio ve Gardner (2005, s. 324)'a göre öz farkındalık ise, kişinin becerilerini, güçlü yönlerini, sahip olduğu değerlerini, inanç ve beklentilerini anlamaya başladığında ortaya çıkan bir süreçtir ve bireyin bilgi, deneyim ve yetenekleri sahip olduğu farkındalığı ortaya çıkarabilir. Walumbwa vd. (2008) bilginin dengeli değerlendirmesini, liderin karar vermeden önce bütün verileri analiz ederek değerlendirmesi şeklinde tanımlamışlar ve bu tip liderlerin genellikle karmaşık konularda itiraz etme yoluna gittiklerini belirtmişlerdir. Ilies vd.. (2005)'ne göre bilginin dengeli değerlendirilmesi, kişisel bütünlüğün ve karakterin merkezindedir. Ayrıca karakter ve dürüstlüğün yalnızca liderlerin vereceği kararları ve uygulayacağı eylemleri etkilemekle kalmayıp, aynı 
zamanda liderin kendisini de rahatlatacağ 1 düşünülmektedir. Kernis (2003, s. 14) ise bilginin dengeli değerlendirilmesini, inkâr etmemek, çarpıtmamak, abartmamak veya göz ardı etmemek şeklinde belirtmiştir. Bunların yerine objektifliği ve kişinin olumlu/olumsuz yönlerini kabullenmesi gerektiğini vurgulamıştır. İçselleştirilmiş ahlak anlayışı, pozitif davranışların ortaya çıkmasında ve çevresel kaynakların oluşturmuş olduğu sorunların çözüme kavuşturulmasında, liderlerin ihtiyaç duydukları rehber niteliğindeki değerleri içermektedir (Karatürk, 2015, s. 19). Luthans ve Avolio (2003), liderliğin doğasında ahlaki bir anlayışın var olduğunu ileri sürmektedirler. Avolio ve Gardner vd. (2005, s. 324), olumlu bir ahlak anlayışı varlığının, otantik liderliğin gelişiminde oldukça önemli olduğunu belirtmişlerdir. Walumbwa vd (2008, s. 95)'ne göre ilişkilerde şeffaflık, kişinin otantik benliğini başkalarına sunmasıdır. Bu tür davranışlar, uygun olmayan duyguların görüntüsünü en aza indirgemeye çalışırken, kişinin gerçek düşünce ve duygularıyla ilgili bilgi ve ifadeleri açıkça paylaşmayı içeren bildirimler sunarak güveni artırır. İlişkisel şeffaflık, başkalarının, sizin için gerçek olanı iyi veya kötü görmesi için önemlidir. Ayrıca, otantik ilişkiler, kendini gizleme süreci, karşılıklı samimiyet ve güven geliştirmeyi içerir. Öz bir ifade ile, kişinin yakınlarıyla olan ilişkilerinde "gerçek" ve "sahte" olmaması anlamına gelir (Kernis, 2003).

Yazında örgütsel bağlılık ile ilgili birçok çalışma ve tanım mevcuttur (Sheldon, 1971; Kanter, 1968; Salancık, 1977; Hall vd., 1970; Grusky, 1966; Mowday, 1982; Becker, 1960; Kement ve Batga, 2016). Sheldon (1971, s. 143) bağl1lı̆̆1, kişiyi örgüte bağlayan bir tutum veya örgüt yönelimi olarak tanımlamıştır. Kanter (1968, s. 499) örgütsel bağlllı̆̆ı, toplumsal aktörlerin enerjilerini, sadakatlerini sosyal sistemlere verme isteği, Salancık (1977, s. 62) bireyin katıldı̆̆ 1 eylem ve faaliyetlerde, kendi inançları doğrultusunda, bağlılığını sürdürmesi, Hall vd. (1970, s. 176) işletmenin ve çalışanların, hedeflerle gittikçe daha çok bütünleşmiş duruma gelme süreci, Grusky (1966, s. 489) çalışanların, bir bütün olarak sistemle olan ilişkisi, Mowday vd. (1982, s. 27) kişinin organizasyonun amaç ve değerlerine inanma ve kabullenme ile organizasyon adına gayret sarf etme isteği, Becker (1960, s. 32) bir kişi yatırım yaptığında ya da bir iş yerinde çalışmaya başladığında, çıkarları doğrultusunda ilişkilendirilen durumun ifadesi olarak tanımlar. Yapılan tanımlardan 
görüleceği üzere örgütsel bağlılık genellikle üç faktör ile karakterize edilebilir (Kraut, 1970; Atchison ve Lefferts, 1972);

- Örgütün hedef ve değerlerine güçlü bir inanç ve kabul gösterme,

- Örgüt adına gayret sarf etmeye istek gösterme,

- Örgütte üyeliğin sürdürülmesi için kesin bir istek duyma.

Hrebiniak ve Alutto (1972, s. 556) örgütsel bağlılığı, değişim ve ödülücret kavramları açısından değerlendirmektedir. Bu yaklaşımda örgütsel bağllık birey ve organizasyon arasındaki pazarlık ya da değişim ilişkileri üzerine kuruludur. Çalışanların bakış açısındaki değişim ne kadar olumlu ise ve elde edilebilecek ödül ne kadar fazla ise sisteme olan bağlılık artar. Allen ve Meyer (1990, s. 3) örgütsel bağl1lı̆̆ 1 üç farklı boyutta ele almıştır. İlk boyut olan duygusal bağlılık, çalışanın kendisini işletmenin bir parçası olarak görmesi durumudur (Yücel ve Çetinkaya, 2015, s. 255). İkinci boyut devam bağlılığı, çalışanların, işletmeden ayrılması durumunda yaşanabilecek olumsuz durumların engellenmesi için kendilerini işletmeye devam etme konusunda bağlamaları durumudur (Meyer ve Allen, 1997, s. 11). Son boyut olan normatif bağlllik ise, çalışanların işletmelerine karşı ahlaki yönden sorumlu hissetmeleri sonucunda, işletmeden ayrılmamanın zorunluluk olarak düşünülmesi halidir (Allen ve Meyer, 1990, s. 3).

Yaşamı anlamlı ve yaşanılabilir kılan bilginin peşinde olan pozitif psikoloji 2000'li yıllardan itibaren araştırmacıların ilgisini çekerek pozitif psikoloji akımı haline gelmiştir. Pozitif psikoloji örgütsel davranış çalışma alanında, pozitif örgütsel davranış olarak karşılığını bulmuş ve psikolojik sermaye çekirdek yapısı altında ölçülebilir ve geliştirilebilir bir kavram olarak tanımlanmıştır (Luthans, 2002a, 2002b). Psikolojik sermaye bireyin, (1) Daha zor durumlarda başarıya ulaşmak için yeterli çabayı sarf etmesi; güveni (öz yeterlilik) (2) Şu an ve gelecekte başarılı olmak için yapılan olumlu durumlarda bulunma; iyimserlik (3) Hedeflere doğru ilerleme ve bu ilerlemelerde yeni yollar bulma; umut (4) Bütün zorluklarda ve karşılaşılan sorunlarda dayanıklılık ve esneklik göstermek; psikolojik dayanıklılık bileşenleri ile karakterize edilen pozitif psikolojik gelişimidir (Avey vd., 2008, s. 4).

Günümüz organizasyonlarının karşı karşıya kaldıkları zorlukların çeşitliliği sıkça dile getirilmektedir. Bu sıkıntıların üstesinden gelmek için insan kaynaklarının, sosyal ve psikolojik kapasitelerini arttırmak ve 
geliştirmek için yenilikçi yollar bulmak daha önemli hale gelmektedir. Örgütler arasında yaşanan "rekabet savaşı" bir anlamda "yetenek savaşı" olarak adlandırılmaktadır. Bu savaş perspektifinden, psikolojik sermaye, içerisinde barındırdığı dört bileşeni ile bugünün ve geleceğin zorluklarının üstesinden gelebilecek bir insan kaynağı gücüdür (Luthans vd., 2007b).

\section{Değişkenler Arasındaki İlişkiler ve Hipotezler}

\subsection{Otantik Liderlik İle Örgütsel Bağlılık Arasındaki İlişki}

Otantik liderler; kendine güvenen, iyimser, geleceğe umutla bakan, çalışanların yeteneklerini ve özelliklerini anlayabilen, davranışlarıyla uyumlu kişiler olarak tanımlanmaktadır. Liderlerin bu özelliklere sahip olmaları, işletme içerisinde örgütsel bağlılık da dâhil olmak üzere pek çok değişkeni etkileyebilir (Yaşbay, 2011, s. 163). Harter vd. (2002) ve Walumbwa vd. (2008) otantik liderliğin, çalışanların davranış ve tutumlarını olumlu şekilde etkileyebileceği ve otantik liderliğin otoriter davranış kalıbı nedeniyle artan örgütsel bağlılık ile doğrudan ilişkili olduğunu belirtmişlerdir. Otantik liderlik ile örgütsel bağl1lık ilişkisine yönelik yazında yer alan çalışmalar ışığında şu hipotez geliştirilmiştir.

$H_{1}$ : Otantik liderlik örgütsel bağglılığı pozitif yönlü ve anlamlı olarak etkiler.

\subsection{Otantik Liderlik İle Psikolojik Sermaye Arasındaki İlişki}

Liderin davranış modeli ve çalışanlarıyla olan ilişkisi (otantik liderlik), olumlu bir iklimi teşvik eder ve çalışanların pozitif psikolojik kapasitelerini geliştirir. Bu durum örgütler için oldukça yararlıdır (Walumbwa vd., 2008). Otantik liderlik, sadece bireylerin davranış ve tutumlarını olumlu yönde etkilemekle ve örgütsel vatandaşlık davranışlarını geliştirmekle kalmaz, aynı zamanda arzu edilen davranış ve performansa ulaşılmasını sağlar (Ilies vd., 2005; Rego vd., 2012). Otantik liderlik, çalışanların pozitif psikolojik kapasitesinin gelişimini arttırarak, öz yeterlilik, umut, iyimserlik ve dayanıklılık düzeylerini yükseltir (Avolio vd., 2004). Bu bağlamda otantik liderlik teorisi psikolojik sermayeye büyük önem vermektedir. Otantik liderlerin psikolojik sermaye boyut- 
ları üzerine olan ilişkisine yönelik yazında yer alan çalışmalar ve bulgular ışığında aşağıdaki hipotez geliştirilmiştir.

$\mathrm{H}_{2}$ : Otantik liderlik, psikolojik sermayeyi pozitif yönlü ve anlaml olarak etkiler.

\subsection{Psikolojik Sermaye ve Örgütsel Bağlılık Arasındaki İlişki}

Örgütlerin arzulanan hedefleri sağlaması ve bu doğrultuda gelişimini arttırması ile psikolojik sermaye, son yıllarda işletmelerin üzerinde durmuş olduğu önemli konulardan birisi haline gelmiştir (Ocak vd., 2016, s. 113). Psikolojik sermaye, işletmelerin rekabet edilebilirlik düzeylerini yukarı taşıyan ve az bulunan bir kaynak durumundadır (Luthans ve Youssef, 2004: 27). Larson ve Luthans (2006) yapmış oldukları çalışmada psikolojik sermayenin örgütsel bağlllı̆g doğrudan etkilediğini tespit etmişlerdir. Psikolojik sermaye ile örgütsel bağlllık üzerine olan ilişkisine yönelik yazında yer alan çalışmalar ve bulgular ışığında aşağıdaki hipotez geliştirilmiştir.

$H_{3}$ : Çalışanlarm psikolojik sermaye seviyeleri, örgütsel bağhllı̆̆ı pozitif yönlü ve anlaml olarak etkiler.

\subsection{Aracılık Etkisi}

Psikolojik sermaye değişkeninin önceki bölümde ele alınan yazında yer alan çalışmalar ışığında otantik liderliğin ve örgütsel bağlılık arasındaki ilişkide aracı etkisi olduğu ve bu ilişkinin yönünün ve şiddetini etkilediği varsayılmıştır. Rego vd. (2016, s. 129) otantik liderlik ile örgütsel bağlllık arasında psikolojik sermayenin aracılık etkisini incelemiş, öz yeterlilik, umut ve iyimserlik boyutlarının söz konusu ilişkiyi anlamlı etkilediği sonucuna varmışlardır. Bu bağlamda aracılık etkisi konusunda aşağıdaki hipotez geliştirilmiştir.

$H_{4}$ : Çalışanlarm psikolojik sermaye seviyelerinin, otantik liderlik ile örgütsel bağhllık arasındaki ilişkide aracı rolü vardır. 


\section{Yöntem}

\subsection{Araștırma Modeli}

Otantik liderlik ile örgütsel bağlllık arasındaki ilişkide psikolojik sermayenin aracılık rolünün araştırıldığ ölçeklerine ilişkin bilgilere yer verilmiştir. Elde edilen veriler Şekil-1'de sunulan araştırma modeli doğrultusunda analiz edilmiştir.

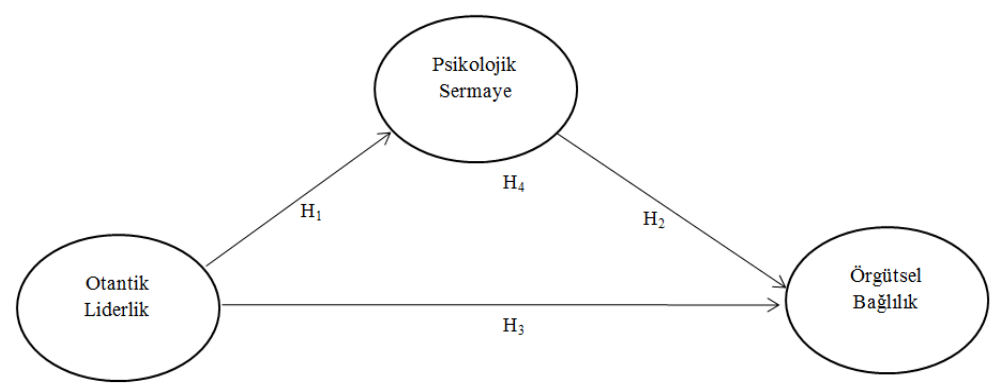

\section{Şekil 1. Araştırma Modeli}

Araştırma modeline göre otantik liderlik ile örgütsel bağlılık arasındaki ilişkide psikolojik sermayenin aracılık rolünün etkisinin var olup olmadığ 1 test edilmiştir.

\subsection{Evren ve Örneklem}

Araştırmada birincil veri toplama yöntemlerinden anket kullanılmıştır. Anket dört bölümden oluşmaktadır. İlk bölümde otantik liderlik ile ilgili 16 soru bulunmaktadır. İkinci bölümde psikolojik sermaye ile ilgili 24 soru yer almaktadır. Üçüncü bölümde örgütsel bağlılığ1 içeren 6 soru, dördüncü ve son bölümde demografik özelliklere ilişkin sorular yer almaktadır. Bingöl Üniversitesinde 710 akademik ve idari personel çalışmaktadır. Kolayda örnekleme yöntemi ile \% 95 güvenilirlik düzeyinde 300 personele ulaşılmış, 295 personele ait veri analiz için uygun bulunmuştur. 


\subsection{Veri Toplama Araçları ve Geçerlilik Güvenirlik Analizleri}

Araştırmada yer alan ölçeklerin geçerliliği Keşfedici Faktör Analizi (KFA) ve Doğrulayıcı Faktör Analizi (DFA) ile incelenmiştir (Gürbüz ve Şahin, 2015, s. 301). KFA ve DFA için verilerin normal dağ 1 lım göstermesi gerekmektedir. Normal dağılım için, -3 ve +3 arasındaki çarpıklık ve basıklık değerleri, kabul edilebilir olarak tanımlanmaktadır (Shao, 2002). Yapılan analizde maddelerin çoğunluğun basıklık ve çarpıklık değerleri -3 ile +3 arasındadır, bu bulgu verilerin normal dağılıma sahip olduğunu göstermektedir.

Çalışmada kullanılan ölçeklerin güvenirliliği Cronbach alfa katsayısı ile ölçülmüsstür. Cronbach alfa değeri 0,60-0,80 arasında ise anket güvenilirdir; 0,80-1,00 arasında ise anketin güvenirliliği oldukça yüksektir (Kalayc1, 2005; Alpar, 2011).

\subsubsection{Otantik Liderlik Ölçeği}

Otantik liderlik ölçeği (16 soru), Walumbwa vd. (2008) çalışmalarını düzenleyen Tabak vd. (2012) tarafından kullanılan şekliyle uygulanmıştır. Çalışmada otantik liderlik ölçeği Cronbach alfa katsayısı 0,89 olarak bulunmuştur.

Otantik Liderlik Ölçeği KMO testi sonunda KMO değeri 0,876 olarak tespit edilmiş olup faktör analizi için örneklem büyüklüğü yeterlidir. Bartlett's Küresellik Testi sonucunda ki-kare değeri 3134,082, serbestlik derecesi değeri (sd) 120 ve $p$ değeri $<0,0001$ bulunmuş olup veriler çok değişkenli normal dağılımdan gelmektedir ve faktör analizine uygundur.

KFA sonucunda tek faktör elde edilmiştir. Ölçeğin faktör yükleri 0,717 ile 0,880 arasında değer aldığı, açıklanan toplam varyansının \% 76,110 olduğu görülmüştür. Ölçeğin yapı geçerliliği test etmek için DFA yapılmıştır. DFA'ya ait uyum iyiliği değerleri Tablo-1'de sunulmuştur.

Tablo 1. Otantik Liderlik Ölçeği Uyum Indeksleri

\begin{tabular}{lccccccc}
\hline Değişken & $\chi^{2}$ & sd & $\chi^{2} /$ sd & GFI & CFI & TLI & RMSEA \\
\hline Kriter & & & $\leq 5$ & $\geq, 85$ & $\geq, 90$ & $\geq, 90$ & $\leq, 08$ \\
$\begin{array}{l}\text { Otantik } \\
\text { Liderlik }\end{array}$ & \multirow{2}{*}{195,606} & \multirow{2}{*}{98} & 1,996 & 0,92 & 0,96 & 0,93 & 0,058 \\
\hline
\end{tabular}


Oluşturulan modelde Ki-kare istatistiğinin serbestlik derecelerine oranı ( $\chi 2 /$ sd) 1,996; yaklaş1k hataların ortalama karekökü (RMSEA) 0,058; Tucker-Lewis indeksi (TLI) değeri 0,93 ve karşılaştırmalı uyum indeks (CFI) değeri ise 0,96 olarak bulunmuştur. Bu kapsamda ölçeğin iyi uyum gösterdiği belirlenmiştir.

KFA ve DFA sonucunda ölçeğin geçerliliği için yeterli kanıt toplanmış $(1,2,3,4,5,10$ nolu sorular hariç) ve yazında Walumbwa vd. (2008) ve Tabak vd. (2012) tarafından geliştirilen ölçeği destekler bulgular elde edilmiştir. Söz konusu ölçek benzer çalışmalarda kullanılabilecek sonuçları vermiştir.

\subsubsection{Psikolojik Sermaye Ölçeği}

İkinci bölümde psikolojik sermaye ile ilgili 24 soru; Luthans vd. (2007a) çalışmalarını düzenleyen Çetin ve Basım (2012) tarafından Türkçeye çevrilmiş haliyle kullanılmıştır. Analizler sonucunda, psikolojik sermayenin alt boyutları için Cronbach alfa katsayısı; öz yeterlilik için 0,85, umut için 0,96, psikolojik dayanıkllık için 0,92, iyimserlik için 0,93 bulunmuştur. Ölçeğin geneline ait Cronbach alfa katsayısı ise, 0,83 olarak bulunmuştur. Bu değerler işığında ölçek genel olarak yeterli güvenilirliğe sahip bulunmuştur.

KMO testi sonunda KMO değeri 0,861 olarak tespit edilmiş olup faktör analizi için örneklem büyüklüğü yeterlidir. Bartlett's Küresellik Testi sonucunda ki-kare değeri 6467,906, serbestlik derecesi değeri (sd) 276 ve p değeri $<0,0001$ bulunmuş olup veriler çok değişkenli normal dağılımdan gelmektedir ve faktör analizine uygundur. KFA sonucunda dört faktör elde edilmiştir. Bu sonuçlar Luthans vd. (2007a) tarafından geliştirilen 4 boyutlu yapıyı desteklemektedir. Ölçeğin faktör yüklerinin, öz yeterlilik boyutu için 0,687 ile 0,815; umut boyutu için 0,907 ile 0,962 ; psikolojik dayanıklılık boyutu için 0,756 ile 0,894; iyimserlik boyutu için 0,782 ile 0,908 arasında değer aldığı, oluşan dört faktörün açıklanan toplam varyansının \% 73,792 olduğu görülmüştür. Ölçeğin yapı geçerliliği test etmek DFA yapılmıştır. DFA'ya ait uyum iyiliği değerleri Tablo-2' de sunulmuştur. 
Tablo 2. Psikolojik Sermaye Ölçeği Uyum İndeksleri

\begin{tabular}{lccccccc}
\hline Değişken & $\chi^{2}$ & sd & $\chi^{2 / s d}$ & GFI & CFI & TLI & RMSEA \\
\hline Kriter & & & $\leq 5$ & $\geq, 85$ & $\geq, 90$ & $\geq, 90$ & $\leq, 08$ \\
Psikolojik & 484,324 & 237 & 2,044 & 0,87 & 0,96 & 0,95 & 0,060 \\
Sermaye & & & & & & & \\
\hline
\end{tabular}

Oluşturulan modelin sunulan uyum indeksleri incelendiğinde: Kikare istatistiğinin serbestlik derecelerine oranı $(\chi 2 / \mathrm{sd}) 2,044$; yaklaşık hataların ortalama karekökü (RMSEA) 0,060; Tucker-Lewis indeksi (TLI) değeri 0,95 ve karşılaştırmalı uyum indeks (CFI) değeri ise 0,96 olarak bulunmuştur. Bu kapsamda ölçeğin iyi uyum gösterdiği belirlenmiştir.

KFA ve DFA sonucunda ölçeğin geçerliliği için yeterli kanit toplanmış ve yazında Luthans vd. (2007a) tarafından geliştirilen 4 boyutlu ve 24 maddeli pozitif psikolojik sermaye ölçeğini destekler bulgular elde edilmiştir.

\subsection{2 Örgütsel Bağlılık Ölçeği}

Örgütsel bağlılığ1 içeren 6 soruluk ölçek; Jaworski ve Kohli (1993) tarafından geliştirilip, Şeşen (2010) tarafından Türkçeye uyarlanmış şekliyle kullanılmıştır. Ölçeğin yanıtları için 5'li likert ölçeği kullanılmıştır. Ölçeğin Cronbach alfa katsayısı 0,82 olarak bulunmuştur.

Örgütsel Bağlılık Ölçeği KMO testi sonunda KMO değeri 0,839 olarak tespit edilmiş olup faktör analizi için örneklem büyüklüğü yeterlidir. Bartlett's Küresellik Testi sonucunda ki-kare değeri 788,074, serbestlik derecesi değeri (sd) 15 ve $\mathrm{p}$ değeri $<0,0001$ bulunmuş olup veriler çok değişkenli normal dağılımdan gelmektedir ve faktör analizine uygundur.

KFA sonucunda tek faktör elde edilmiştir. Ölçeğin faktör yükleri 0,756 ile 0,890 arasında değer aldığ 1 (6'ncı madde faktör yükü 0,50 nin altında olduğundan ölçekten çıkarılmıştır), açılanan toplam varyansının \% 56,577 olduğu görülmüştür. Ölçeğin yapı geçerliliği test etmek için DFA yapılmıştır. DFA'ya ait uyum iyiliği değerleri Tablo-3-'te sunulmuştur. 
Tablo 3. Örgütsel Bağlllık Ölçeği Uyum İndeksleri

\begin{tabular}{lccccccc}
\hline Değişken & $\chi^{2}$ & sd & $\chi^{2} / \mathbf{s d}$ & GFI & CFI & TLI & RMSEA \\
\hline Kriter & & & $\leq 5$ & $\geq, 85$ & $\geq, 90$ & $\geq, 90$ & $\leq, 08$ \\
Ö. Bağlılık & 5,769 & 3 & 1,923 & 0,99 & 0,99 & 0,98 & 0,056 \\
\hline
\end{tabular}

Oluşturulan modelin sunulan uyum indeksleri incelendiğinde: Kikare istatistiğinin serbestlik derecelerine oranı $(\chi 2 / \mathrm{sd}) 1,923$; yaklaşık hataların ortalama karekökü (RMSEA) 0,056; Tucker-Lewis indeksi (TLI) değeri 0,98 ve karşılaştırmalı uyum indeks (CFI) değeri ise 0,99 olarak bulunmuştur. Bu kapsamda ölçeğin iyi uyum gösterdiği belirlenmiştir. KFA ve DFA sonucunda ölçeğin geçerliliği için yeterli kanıt toplanmıştır.

\section{Araştırma Modelinin Test Edilmesi ve Bulgular}

Önceki bölümlerde değişkenler arasındaki kavramsal ilişkiler önceki bölümlerde açılanmıştır. Araştırmanın temel hipotezleri doğrultusunda kavramsal ilişkiler elde edilen veriler çerçevesinde irdelenmiştir. Araştırmada değişkenler arasındaki ilişkilerin ortaya çıkarılması amacıyla korelasyon analizi yapılmış, analiz sonuçları Tablo-4'te sunulmuştur.

Tablo 4. Korelasyon Analizi Sonuçları

\begin{tabular}{|c|c|c|c|c|c|c|c|c|c|c|c|}
\hline & 1 & 2 & 3 & 4 & 5 & 6 & 7 & 8 & 9 & 10 & 11 \\
\hline 1. G.O.L. & 1 & & & & & & & & & & \\
\hline 2. İ.Ş. &, $591^{* *}$ & 1 & & & & & & & & & \\
\hline 3. A. A. & , $801^{* *}$ & $291^{* *}$ & 1 & & & & & & & & \\
\hline 4. B.D.D. & $647^{* *}$ & , 100 & $372^{* *}$ & 1 & & & & & & & \\
\hline 5. Ö. F. & $804^{* *}$ & $, 213^{* *}, 6$ & $618^{* *}$ & $453^{* *}$ & 1 & & & & & & \\
\hline 6. P.S. & $156^{* *}$ & ,068 & $150^{* *}$ & $130^{*}$ & ,102 & 1 & & & & & \\
\hline 7. İ. &, 072 &, 030 &, 076 &, 062 &, 040 &, $596^{* *}$ & 1 & & & & \\
\hline 8. P. D. & ,015 &,- 016 & ,006 & ,084 &,- 020 &, $491^{* *}$ &,- 068 & 1 & & & \\
\hline 9.Ö.Y. & $189^{* *}$ & $138^{*}$ & $117^{* *}$ & ,113 & $165^{* *}$ & $669^{* *}$ & $148^{*}$ &, $310^{* *}$ & 1 & & \\
\hline 10.U. & ,069 &,- 003 & $132^{*}$ & ,030 & , 040 & $412^{* *}$ & $-0,63$ &,- 013 & 0,93 & 1 & \\
\hline 11.Ö. B. & $260^{* *}$ & , 078 & $226^{* *}$ &, $224^{* *}$ & $222^{* *}$ & $338^{* *}$ & $120^{*}$ & $172^{* *}$ &, $396^{* *}$ & ,079 & 1 \\
\hline \multicolumn{12}{|c|}{${ }^{*} \mathrm{p}<0.05,{ }^{* *} \mathrm{p}<0.01,{ }^{* * *} \mathrm{p}<0.001$} \\
\hline \multirow{3}{*}{\multicolumn{3}{|c|}{$\begin{array}{l}\text { G.O.L: Genel Otantik Liderlik } \\
\text { B.D.D: Bilgiyi Dengeli Değerlendirme } \\
\text { İ: İyimserlik }\end{array}$}} & \multicolumn{3}{|c|}{ İ.Ş: İliş̧kilerde Şeffaflık } & \multicolumn{3}{|c|}{ A.A: Ahlak Anlayış } & & & \\
\hline & & & \multicolumn{3}{|c|}{ Ö.F: Öz Farkındalık } & \multirow{2}{*}{\multicolumn{4}{|c|}{$\begin{array}{l}\text { P.S: Psikolojik Sermaye } \\
\text { ÖY. Öz Yeterlilik }\end{array}$}} & & \\
\hline & & & P.D: & Psikoloji & Dayanık & & & & & & \\
\hline \multicolumn{3}{|l|}{ U: Umut } & Ö.B: & & Bağllilık & & & & & & \\
\hline
\end{tabular}


Tablo-4'te sunulduğu üzere korelasyon katsayıları dikkate alındığında değişkenler arasında genel olarak anlamlı ilişkilerin bulunduğu görülmektedir. Bağımsız değişken otantik liderlik ile psikolojik sermaye, alt boyutlarından öz yeterlilik boyutu ve örgütsel bağlılık arasında anlamlı ilişki bulunmaktadır. Bağımlı değişken örgütsel bağlılık ile otantik liderlik, alt boyutlarından ahlak anlayışı ve bilgiyi dengeli değerlendirme, psikolojik sermaye, alt boyutlarından iyimserlik, psikolojik dayanıklılık ve öz yeterlilik arasında anlamlı ilişki bulunmaktadır. Gerçekleştirilen regresyon analizine göre araştırmada ölçülmesi hedeflenen " $\mathrm{H}_{1}, \mathrm{H}_{2}$ ve $\mathrm{H}_{3}$ " hipotezleri test edilmiştir.

Tablo 5. Otantik Liderlik ile Örgütsel Bă̆lılı̆ın Hiyerarşik Regresyon Sonuçlar

\begin{tabular}{|c|c|c|c|c|}
\hline & \multicolumn{3}{|c|}{ Örgütsel Bă̆lılık } & \\
\hline & $\beta$ & & $t$ & \\
\hline İliş. Şeffaflik & 0,012 & & 0,196 & \\
\hline A. Anlayışı & 0,119 & & 1,608 & \\
\hline Bilg. Deng. Değerlen. & 0,141 & & $2,210^{* *}$ & \\
\hline Ö. Farkındalık & 0,082 & & 1,093 & \\
\hline Genel Otantik Liderlik & & 0,260 & & $4,601^{* *}$ \\
\hline Düzeltilmiş R2 & & & & \\
\hline $\mathrm{F}$ & & & 02 & \\
\hline
\end{tabular}

Tablo-5'e göre genel otantik liderliğin $(\beta=0,260, p<0,01)$ ve otantik liderlik boyutlarından yalnızca bilgiyi dengeli değerlendirme boyutunun örgütsel bağlılığı $(\beta=0,141, p<0,01)$, açıkladığı görülmektedir. Bu sonuç otantik liderlik davranışı ve bilgiyi dengeli değerlendirmenin artıkça, örgütsel bağlılığın arttığını göstermektedir. Otantik liderlik açısından elde edilen bulgular çalışmanın birinci hipotezini kısmen doğrulamaktadır.

Tablo-6'ya göre genel otantik liderliğin $(\beta=0,156, p<0,01)$ genel psikolojik sermayeyi, alt boyutlarından öz yeterliliği $(\beta=0,189, p<0,01)$, otantik liderlik alt boyutlarından ahlak anlayışının $(\beta=0,132, p<0,05)$ umut boyutunu açıkladığı görülmektedir. Otantik liderlik açısından elde edilen bulgular çalışmanın ikinci hipotezini doğrulamaktadır. 
Tablo 6. Otantik Liderlik ile Psikolojik Sermayenin Hiyerarşik Regresyon Sonuçları

\begin{tabular}{|c|c|c|c|c|c|c|c|c|c|c|}
\hline & \multicolumn{2}{|c|}{ İ. } & \multicolumn{2}{|c|}{ P.D. } & \multicolumn{2}{|c|}{$\mathrm{U}$} & \multicolumn{2}{|c|}{ Ö. Y. } & \multicolumn{2}{|c|}{ G.P.S } \\
\hline & $\beta$ & $\mathrm{t}$ & $\beta$ & $t$ & $\beta$ & $\mathrm{t}$ & $\beta$ & $\mathrm{t}$ & $\beta$ & $\mathrm{t}$ \\
\hline İ. Ş. & 0,010 & 0,160 & $-0,015$ & $-0,247$ & $-0,45$ & $-0,743$ & 0,41 & 0,571 & $-0,038$ & $-0,527$ \\
\hline A. A. & 0,073 & 0,950 & 0,015 & 0,198 & 0,132 & $2,276^{*}$ & $-0,097$ & $-1,016$ & 0,071 & 0,734 \\
\hline $\begin{array}{l}\text { B. } \\
\text { D.D }\end{array}$ & 0,046 & 0,700 & 0,115 & 1,737 & $-0,022$ & $-0,349$ & $-0,016$ & $-0,208$ & 0,051 & 0,668 \\
\hline Ö. F. & $-0,028$ & $-0,354$ & $-0,078$ & $-0,994$ & $-0,066$ & $-0,901$ & 0,038 & 0,391 & $-0,067$ & $-0,691$ \\
\hline $\begin{array}{l}\text { G. O. } \\
\text { L. }\end{array}$ & 0,072 & 1,232 & 0,015 & 0,257 & $-0,102$ & $-1,056$ & 0,189 & $3,298^{* *}$ & 0,156 & $2,702^{* *}$ \\
\hline $\begin{array}{l}\text { Düzel } \\
\text { til. R2 }\end{array}$ & \multicolumn{2}{|c|}{0,6} & \multicolumn{2}{|c|}{$-0,20$} & \multicolumn{2}{|c|}{0,14} & \multicolumn{2}{|c|}{0,33} & \multicolumn{2}{|c|}{0,21} \\
\hline $\mathrm{F}$ & \multicolumn{2}{|c|}{0,553} & \multicolumn{2}{|c|}{0,839} & \multicolumn{2}{|c|}{5,180} & \multicolumn{2}{|c|}{10,877} & \multicolumn{2}{|c|}{7,300} \\
\hline \multicolumn{11}{|c|}{${ }^{*} p<0,05,{ }^{* *} p<0,01$} \\
\hline \multirow{3}{*}{\multicolumn{4}{|c|}{$\begin{array}{l}\text { G.O.L: Genel Otantik Liderlik } \\
\text { B.D.D: Bilgiyi Dengeli Değerlendirme } \\
\text { İ: İyimserlik }\end{array}$}} & \multicolumn{3}{|c|}{ I.Ş: Illişkilerde Şeffaflık } & \multicolumn{4}{|c|}{ A.A: Ahlak Anlayışı } \\
\hline & & & & \multicolumn{3}{|c|}{ P.S: Psikolojik Sermaye } & \multicolumn{4}{|c|}{ Ö.F: Öz Farkındalık } \\
\hline & & & & P.D: & ikolojik & ayanikli & & Ö.Y: Öz & eterlili & \\
\hline \multicolumn{4}{|c|}{ Ö.B: Örgütsel Bă̆lılık } & \multicolumn{4}{|c|}{ G.P.S: Genel Psikolojik Sermaye } & U: Umut & & \\
\hline
\end{tabular}

Tablo-7'ye göre psikolojik sermaye çekirdek yapısının $(\beta=0,338$, $\mathrm{p}<0,01)$ ve psikolojik sermaye boyutlarından sadece öz yeterlilik boyutunun örgütsel bağlılığ1 $(\beta=0,359, \mathrm{p}<0,01)$ açıladığı görülmektedir. Bu sonuç psikolojik sermaye ve alt boyutlardan öz yeterliliğin artıkça, örgütsel bağlılı̆̆ın arttığını göstermektedir. Psikolojik sermaye açısından elde edilen bulgular çalışmanın üçüncü hipotezini kısmen doğrulamaktadir.

Tablo 7. Psikolojik Sermaye ile Örgütsel Bağlılık Hiyerarşik Regresyon Sonuçlar

\begin{tabular}{|c|c|c|}
\hline & \multicolumn{2}{|c|}{ Örgütsel Bağlılık } \\
\hline & $\beta$ & $\mathrm{t}$ \\
\hline İyimserlik & 0,074 & 1,351 \\
\hline P. Dayanıklılık & 0,066 & 1,159 \\
\hline Umut & 0,051 & 0,941 \\
\hline Ö. Yeterlilik & 0,359 & $6,231^{* *}$ \\
\hline Genel Psikolojik Sermaye & 0,338 & $6,143^{* *}$ \\
\hline Düzeltilmiş R2 & \multicolumn{2}{|c|}{0,15} \\
\hline $\mathrm{F}$ & \multicolumn{2}{|c|}{14,467} \\
\hline
\end{tabular}

Çalı̧̧manın son hipotezi olan $H_{4}$, psikolojik sermaye ve alt boyutlarının otantik liderlik ile örgütsel bağlılık arasındaki ilişkide bir aracılık rolünün olup olmadığının ortaya çıarılması için geliştirilmiştir. Aracılık ilişkisinin ispat edilmesi için bazı koşulların sağlanması gerekmektedir. Bu koşullar; 
- Bağımlı değişken ile bağımsız değişken arasında anlamlı bir ilişki olmalıdır.

- Bağımsız değişken ile aracı değişken arasında anlamlı bir ilişki olmalıdır.

- Bağımsız değişken ile model içerisinde kullanıldığında, aracı değişken ile bağımlı değişken arasında anlamlı bir ilişki olmalıdır.

- Bağımsız değişken ile aracı değişken bağımsız değişkenle birlikte regresyon analizine dâhil edildiğinde, bağımsız değişkenin bağımlı değişken üzerindeki etkisi düşerken, aracı değişkenin de bağımsız değişken üzerinde anlamlı bir etkisi olmalıdır (Baron ve Kenny'den [1986] aktaran Meydan ve Şeşen, 2015, s. 130).

Söz konusu ilk üç koşul sağlandığından dördüncü koşulun gerçekleşip gerçekleşmediği araştırılabilecektir. Aracı değişken, regresyon analizine dâhil edildiğinde, bağımsız değiş̧kenin bağımlı değişken üzerindeki etkisi tamamen aracı değişken üzerinden gerçekleşiyorsa tam aracılık, bağımsız değişken ile bağımlı değişken arasındaki ilişkide azalma meydana geliyorsa kısmi aracılık etkisinden söz edilir Aracılık ilişkisi için yapılan regresyon analizi sonuçları Tablo8 'de sunulmuştur.

Tablo 8. Otantik Liderlik ve Örgütsel Bağlılık Arasındaki ilişkide Psikolojik Sermayenin Aracılık Rolü

\begin{tabular}{lcc}
\hline & \multicolumn{2}{c}{ Örgütsel Bağllık } \\
\hline $\mathbf{1}$ İyimserlik & $\beta$ & $\mathrm{t}$ \\
$\quad$ P. Dayanıklılık & 0,103 & 1,811 \\
$\quad$ Umut & 0,170 & $3,036^{*}$ \\
$\quad$ Ö. Yeterlilik & 0,050 & 0,867 \\
\hline Genel Psikolojik Sermaye & 0,374 & $7,055^{* *}$ \\
\hline $\mathbf{2}$ İ. Şeffaflık & 0,305 & $5,605^{* *}$ \\
A. Anlayışı & 0,013 & 0,224 \\
Bilgi. Den. Değerlendirme & 0,165 & $2,725^{*}$ \\
Ö. Farkındalık & 0,162 & $2,674^{*}$ \\
\hline Gen. Otantik Liderlik & 0,134 & 1,858 \\
\hline Düzeltilmiş R2 & 0,212 & $3,901^{* *}$ \\
F & & \\
\hline${ }^{*} p<0,05,{ }^{* *} p<0,01$ & & 0,19 \\
\end{tabular}

Yapılan analiz sonucunda genel otantik liderliğin, örgütsel bağlllık üzerindeki etkisi $(\beta=0,212, \mathrm{p}<0,01)$ düzeyindedir. Psikolojik sermaye (öz 
yeterlilik) değişkenlerinin regresyona dâhil edilmesi ile doğrudan etki düzeyinde $(\beta=0,260, p<0,01)$ bir değer azalması olduğu görülmektedir. Bu sonuç psikolojik sermaye çekirdek yapısının (öz yeterliliğin) otantik liderliğin, örgütsel bağl1lık üzerindeki etkisinde kısmi aracı rolü olduğunu göstermektedir. Bulgular çalışmanın H4 hipotezini kısmen doğrulamaktadır.

Bulunan sonuçların doğruluğunu kanıtlamak için Sobel testi uygulanmıştır (Baron ve Kenny, 1986, s. 1175). Şekil 2'de verilen bağımsız değişkenin araciya giden yoluna " $\mathrm{X}$ " ve standart hatasına, "SX"; aracıdan bağımlı değişkene giden yola " $Y$ " ve standart hatası, "SY" olarak gösterilmektedir.

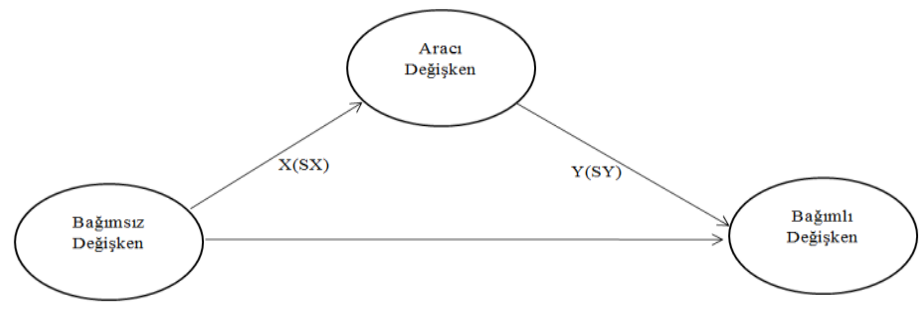

Şekil 2. Sobel Testi

Aracinin Anlamllik Düzeyi $=\sqrt{ }\left(Y^{*} S X\right)^{2}+\sqrt{ }\left(X^{*} S Y\right)^{2}+\sqrt{ }(S X * S Y)^{2}$

Anlamlllkk Düzeyi $=\sqrt{ }\left(0,192^{*} 0,056\right)^{2}+\sqrt{ }(0,189 * 0,058)^{2}+\sqrt{ }\left(0,056^{*} 0,058\right)^{2}$

Testi uygulamak için regresyon sonuçlarından alınan veriler, denklemde yerine yerleştirildiğinde anlamlılık düzeyi $0.024(0,024962)$ olarak bulunmuştur. Dolayısıyla, psikolojik sermayenin öz yeterlilik boyutu, Sobel testinde ortaya çıkan sonuçlara göre de anlamlı olup, aracılık özelliği taşımaktadır ( $\mathrm{p}<0.05)$. Buna göre, "H4" hipotezi kısmen kabul edilmiştir.

\section{Sonuç ve Tartışma}

Çalışma sonucunda otantik liderliğin ve otantik liderlik boyutlarından yalnızca bilgiyi dengeli değerlendirme boyutunun örgütsel bağlılığı, otantik liderliğin, psikolojik sermaye çekirdek yapısını ve öz yeterlilik 
boyutunu, otantik liderlik alt boyutlarından ahlak anlayışının, psikolojik sermayenin umut boyutunu açıladığı görülmektedir. Psikolojik sermaye çekirdek yapısının ve psikolojik sermaye boyutlarından sadece öz yeterlilik boyutunun örgütsel bağlılığı pozitif yönlü etkilediği ve psikolojik sermaye çekirdek yapısının (öz yeterliliğin) otantik liderliğin, örgütsel bağlllık üzerindeki etkisinde kısmi aracı rolü olduğu tespit edilmiştir.

Çalışmamızda incelenen değişkenler ve değişkenler arasındaki ilişkiler, değişkenlerin günümüzdeki popülaritesine bağlı olarak ulusal ve uluslararası yazında konu edilmiştir. Otantik liderlik ve örgütsel bağlılık arasında yapılan çalışmalarda örgütsel bağlılı̆̆ın temel belirleyicisinin liderlik anlayışı olduğu ve otantik liderliğin örgütsel bağlllı̆̆1 pozitif ve anlamlı olarak etkilediği sonucuna ulaşılmıştır (Avolio vd., 2004; Gardner ve Schermerhorn, 2004; Rego vd., 2016; Yaşbay, 2011; Kahn; 1990). Özellikle çalışanların psikolojik olarak desteklendiği ortamlarda işe bağlılığının arttığı ve kendini işletmenin bir parçası olarak hissettiği yapılan çalışmalarda tespit edilmiştir. Çalışmamızda elde edilen sonuçlar ulusal ve uluslararası yazında yapılan çalışmaları desteklemektedir. Otantik liderlik davranışı, örgütsel bağlılı̆̆ı pozitif yönde etkileyerek çalışanların örgütlerine daha bağlı olmalarını sağlamaktadır.

Alan yazında otantik liderlik davranışının çalışanların psikolojik sermayelerini yükselttiği ve liderliğin psikolojik sermayenin öz yeterlilik, umut, iyimserlik ve dayanıklılık kaynakları aracılığıyla işletmelerini geliştirebilecekleri belirtilmiştir (Gardner ve Schermerhorn, 2004; Tugade vd., 2004; Bozgeyikli, 2017; Gardner vd., 2005; Norman vd., 2005; Ilies vd., 2005; Keser ve Kocabaş, 2014; Jensen ve Luthans, 2006; Karatürk, 2015). Çalışmalar ayrıca umut, dayanıklılık, iyimserlik ve öz yeterlilik boyutlarının, liderlerin algılama biçimlerinin ve psikolojik kapasitelerinin gelişimde etkili olduğunu önermiştir.

Otantik liderler, çalışanların öz yeterliliklerini ortaya çıkararak, onların var olan potansiyellerini görmelerine ve sürekli gelişmelerine yardımcı olmaktadır. Bu durum bir süre sonra kendini tekrar eden bir hal alır (Avolio vd., 2004; Gardner vd., 2005; Luthans vd., 2007b). Otantik liderler, çalışanlarla açı bir şekilde bilgi paylaşırken, çalışanların kendine güvenlerini kazanmasını beklerler (Walumbwa vd., 2008). De 
Hoogh ve Den Hartog (2008), liderlik modelinin çalışanların gelecekleri konusunda iyimserlikleri ile önemli ölçüde ilişkili olduğunu önermektedir. Çalışmamamızda elde edilen sonuçlar otantik liderlik davranışının çalışanların psikolojik sermayelerini yükselttiğini ortaya koymaktadır. $\mathrm{Bu}$ bağlamda otantik liderlik çalışanların pozitif psikolojik kapasite (kaynaklarını) yükseltmek (mobilize etmek) için başvurulabilecek yönetimsel uygulamalardan bir tanesidir.

Luthans vd. (2007b), psikolojik sermayenin her bir boyutunun geliştirilebileceğini, boyutların çalışanların tutum, davranış ve performans üzerinde önemli bir etkisi olduğunu belirtmişler, psikolojik sermayenin gelişiminin çalışanların tutumları üzerinde etki sağladığını vurgulamışlardır. Benzer çalışmalarda da psikolojik sermayenin örgütsel bağlılı̆̆ı anlamlı ve pozitif bir şekilde etkilediği tespit edilmiş olup, çalışanların, iyimser ve öz yeterliliklerine inanmaları halinde işletmelerinde daha başarılı olacakları ve çalıştıkları kuruma karşı kendilerini daha bağlı hissedecekleri belirtilmiştir (Youssef ve Luthans, 2007; Avey vd., 2011; Avc1 ve Bozgeyikli, 2017; Luthans vd., 2008; Laschinger vd., 2009; Ocak vd., 2016). Çalışmamızda elde edilen bulgular psikolojik sermayenin çalışanlar ve organizasyonel açısından pek çok olumlu sonucunun olduğu tezini güçlendirmiş ve psikolojik sermayenin örgütsel bağlılı̆̆ı artırdığını ortaya koymuştur.

Rego vd. (2016, s. 129) otantik liderlik ile örgütsel bağlllık arasında psikolojik sermayenin aracılık etkisini incelemiş ve öz yeterlilik, umut ve iyimserlik boyutlarının söz konusu ilişkiyi anlamlı etkilediği sonucuna varmışlardır. Çalışmamızda psikolojik sermaye çekirdek yapısının (öz yeterliliğin) otantik liderliğin, örgütsel bağlılık üzerindeki etkisinde kısmi aracı rolü olduğu tespit edilmiştir. Bu bağlamda psikolojik sermayenin (öz yeterlilik) artırılması ile otantik liderlik ve örgütsel bağlılık ilişkisinin daha fazla kuvvetlenebileceği tespit edilmiştir. Karatürk (2015, s. 111) İstanbul'da bir elektronik sektöründe 287 beyaz yaka çalışanı ile yapmış olduğu çalışmasında otantik liderlik bileşenleri ile çalışanların psikolojik sermaye arasında pozitif yönlü bir ilişki olduğunu tespit etmiştir. Çalışmada ayrıca psikolojik sermaye düzeyi yüksek olan çalışanların, örgütlerinin gelişiminde önemli rol oynadıkları ve bu anlamda otantik liderlerin, ahlaki davranış ve şeffaf kişilikleriyle, çalışan- 
lara güven aşılayarak örgüte olan bağl1lıklarını arttırdığı tespit edilmiştir.

Ülkemizde yapılan çalışmalarda genel olarak otantik liderliğin örgütsel bağlllığı (Terzi ve Kurt, 2005; Yaşbay, 2011; Doğanay, 2014; Işkın ve Kaygın, 2016), otantik liderliğin psikolojik sermaye düzeylerini (Keser ve Kocabaş, 2014; Karatürk, 2015; Saylı ve Baytok, 2014; Savur, 2013; Keser, 2013) ve örgütsel bağlllık ile psikolojik sermaye düzeyleri arasında anlamlı ve pozitif etkilerin görüldüğü tespit edilmiştir (Ocak vd, 2016; Çetin, 2011; Çınar, 2011). Alan yazında otantik liderlik ve örgütsel bağllık arasındaki ilişkide psikolojik sermayenin aracılık rolü ile ilgili bir çalışmanın olmadığı tespit edilmiştir. Çalışmalar yukarıda bahsedildiği gibi değişkenlerin birbirleri arasındaki ilişkilerin ölçülmesi şeklinde gerçekleştirilmiştir.

Genel olarak bakıldığında çalışmamızda elde edilen sonuçlar ulusal ve uluslararası yazında yapılan çalışmaları desteklemektedir. İnsan ve sosyal sermayenin üçüncü jenerasyonu olan psikolojik sermaye organizasyonlara rekabet avantajı sunan birçok örgütsel davranış ile ilişkilendirilmektedir. Pozitif psikolojik sermaye ve alt bileşenleri örgütler için gelecek vaat eden yapılardır. Yöneticilerin bu yapıları iyi analiz etmesi, gerektiğinde profesyonel destek alarak çalışanlarının pozitif ve güçlü yönlerinin ortaya çıkarılarak geliştirilmesi ve psikolojik sermayelerinin yükseltilmesi beraberinde pek çok pozitif sonucu beraberinde getirecektir (Okun, 2017). Bu bağlamda elde edilen sonuçlar otantik liderlik davranışı ve psikolojik sermayenin işletmeye daha yüksek bir örgütsel bağlllık olarak döndüğünü işaret etmektedir. Daha yüksek bir örgütsel bağlılık ise işletme ve çalışan için pek çok pozitif çıktıyı beraberinde getirecek, işletmeye rekabet avantajı kazandıracaktır. Ayrıca çalışmamızda kullanılan ölçeklerin KFA ve DFA yapılarak geçerliliklerinin ortaya koyulması ile söz konusu ölçeklerin benzer çalışmalarda kullanılabileceği önerilmektedir.

$\mathrm{Bu}$ faaliyet daha da kapsamlı olacak şekilde yapılması gerektiği düşünülebilir. Hatta farklı işletmeler ziyaret edilerek kıyaslamalarda bulunulabilir. Diğer liderlik tipleri üzerine de çalışmalar gerçekleştirilebilir. Ayrıca gelecekte psikolojik sermayenin tatmin, sadakat, deneyim, güven üzerine olan etkileri de derinlemesine incelenerek analizleri yapilabilir. 
EXTENDED ABSTRACT

\title{
The Mediation Effect of Psychological Capital Between Authentic Leadership and Organizational Commitment: The Case of Bingöl University
}

\author{
* \\ Tuba Büyükbeşe - Sinan Çavuşoğlu - Olcay Okun \\ Hasan Kalyoncu University - Bingöl University - Ministry of National Defense
}

In recent years, the economic, political and technological developments have increased the need of enterprises for the leaders, who adopt a transparent and ethical management approach and are aware of the organization and its values. In this context, authentic leadership from today's modern leadership styles stands out. Authentic leaders help their employees to understand their work and life (Gardner et al., 2005).

In line with their values, beliefs and opinions, authentic leaders establish transparent, principled, honest and genuine relationships (Gardner et al., 2005; Ilies et al., 2005, Walumbwa et al., 2008; Kernis, 2003). This will enable enterprise to reach their goals and objectives faster.

Organizational commitment is considered to be a fanatic and emotional commitment to the organization as well as its amity and loyalty to the goals and values of employees in the organization. In addition, organizational commitment is an important and strong acceptance in terms of the effectiveness and continuity of enterprises (Buchanan, 1974, p. 533).

Psychological capital is considered as a premise in the development of authentic leadership style (Luthans and Avolio, 2003). It is envisaged that the development of psychological capital of employees is one of the main components of authentic leadership style (Luthans et al., 2007b).

Authentic leadership style has been studied by many researchers and has been found to have a positive effect on organizational commitment (Luthans and Avolio, 2003; Pittinsky and Tyson, 2005; Shamir and Eilam, 2005; Gardner et al., 2005; , 2008). In the literature, there are studies in- 
vestigating the relationship between authentic leadership and psychological capital (Avolio et al., 2004; Tugade et al., 2004; Gardner et al., 2005; Norman et al., 2005; Ilies et al., 2005; Hoogh and Den Hartog, 2008). These studies generally suggest that authentic leadership encourages psychological capital and positive emotions (Rego et al., 2012). In the light of these empirical studies, it is seen that enterprises tend to lead the leadership and leadership role to find the way to ensure the organizational commitment of employees (Luthans and Avolio, 2003).

As a result of the study, it is seen that authentic leadership and balanced processing (authentic leadership dimension) affected positively organizational commitment. Authentic leadership explains psychological capital core structure and self-efficacy dimension, self regulation (authentic leadership dimensions) explains hope (psychological capital dimension). Also it was found that psychological capital core structure and only the self-efficacy (psychological capital dimension) affected the organizational commitment positively and that the psychological capital core structure (self-efficacy) had a partial mediator role in the effect of authentic leadership on organizational commitment.

Studies conducted between authentic leadership and organizational commitment concluded that the main determinant of organizational commitment is leadership and that authentic leadership affects organizational commitment positively and significantly (Avolio et al., 2004; Gardo and Schermerhorn, 2004; Yaşbay, 2011; Kahn; 1990). It has been determined in the studies that increased the loyalty of the employees and felt as part of the enterpise especially in the environments where the employees are supported psychologically. The results obtained in our study support the national and international literature. Authentic leadership behavior positively affects organizational commitment and enables employees to be more committed to their organizations.

Authentic leaders help employees to see their potentials and develop continuously. This situation recurred after a while (Avolio et al., 2004; Gardner et al., 2005; Luthans et al., 2007b). When authentic leaders share information with employees, they expect employees to gain selfconfidence (Walumbwa et al., 2008). De Hoogh and Den Hartog (2008) suggest that the leadership model is significantly related to the optimism of employees about their future. The results obtained in this study reveal 
that authentic leadership behavior increases the psychological capital of employees. In this context, authentic leadership is one of the managerial practices that can be used to raise (mobilize) positive psychological capacity of employees.

Luthans et al. (2007b) stated that each dimension of psychological capital could be improved, and that the dimensions had a significant impact on the attitudes, behavior and performance of the employees. In similar studies, it has been determined that psychological capital affects organizational commitment in a meaningful and positive direction, and it is stated that if employees believe in optimistic and self-efficacy, they will be more successful in their enterprises and they will feel more connected to the enterpise they work with (Youssef and Luthans, 2007; Avey et al., 2011; Luthans et al., 2008; Laschinger et al., 2009; Ocak et al., 2016). The findings of this study have strengthened the thesis that psychological capital has many positive results in terms of employees and organizations, and that psychological capital increases organizational commitment.

Rego et al. (2016, p. 129) examined the mediating effect of psychological capital between authentic leadership and organizational commitment, and concluded that the dimensions of self-efficacy, hope and optimism significantly affected the relationship between them. In this study, it has been determined that the core structure of the psychological capital (self-efficacy) has a partial mediator role in the effect of authentic leadership on organizational commitment. In this context, it was determined that the increase of psychological capital (self-efficacy) and the relationship between authentic leadership and organizational commitment could be strengthened more. Karatürk (2015, p. 111) found a positive relationship between authentic leadership components and psychological capital. It was also found that employees with high psychological capital level played an important role in the development of their organizations and in this sense authentic leaders increased their commitment to the organization by instilling trust in employees with their moral behaviors and transparent personalities.

Psychological capital, the third generation of human and social capital, is associated with many organizational behaviors that offer competitive advantage to organizations. Positive psychological capital and its 
dimensions are promising structures for organizations. Good analysis of these structures by executives, professional support by developing and developing positive and strong aspects of their employees and raising their psychological capital will bring along many positive results (Okun, 2017).The results in this context indicate that authentic leadership behavior and psychological capital return to the enterprise as a higher organizational commitment. A higher organizational commitment will bring many positive outcomes for the enterprise and the employee and will bring a competitive advantage to the business. In addition by making KFA and DFA validity, it is suggested that the scales used in our study can be used in similar studies.

\section{Kaynakça / References}

Allen, N. J., ve Meyer, J. P. (1990). The measurement and antecedents of affective, continuance and normative commitment to the organization. Journal Of Occupational And Organizational Psychology, 63(1), 1-18.

Alpar, R. (2011). Uygulamalı çok değişkenli istatistiksel yöntemler. Ankara: Detay Yayıncilik.

Atchison, T. ve Lefferts, E. A. (1972). The prediction of turnover using Herzberg's job satisfaction technique. Personnel Psychology, 25(1), 53-64.

Avcı, A. ve Bozgeyikli, H. (2017). Okul yöneticilerinin yönetici kayg1 düzeylerinin yordayıcısı olarak psikolojik sermaye. Marmara $\ddot{U} n-$ iversitesi Atatürk Eğitim Fakültesi Ĕ̆itim Bilimleri Dergisi, 45, 43-57.

Avey, J. B., Luthans, F. ve Youssef, C. M. (2008). The additive value of positive psychological capital in predicting work attitudes and behaviors. Leadership Institute Faculty Publications, Paper 6,1-42.

Avey, J. B., Reichard, R. J., Luthans, F., ve Mhatre, K. H. (2011). Metaanalysis of the impact of positive psychological capital on employee attitudes, behaviors, and performance. Human Resource Development Quarterly, 22(2), 127-152. 
Avolio, B. J., Luthans, F., ve Walumbwa, F. O. (2004). Authentic Leadership: Theory building for veritable sustained performance working paper. Gallup Leadership Institute, University of Nebraska, Lincoln.

Avolio, Bruce J. ve Gardner, W. L. (2005). Authentic Leadership Development: Getting to the Root of Positive Forms of Leadership. The Leadership Quarterly, Vol.16, s.315-338.

Baron, R. M. ve Kenny, D. A. (1986). The Moderator-Mediator Variable Distinction in Social Psychological Research: Conceptual, Strategic, and Statistical Considerations. Journal of Personality and Social Psychology, 51(6), 1173.

Becker, H. S. (1960). Notes on the concept of commitment. American Journal of Sociologv, 66, 32-42.

Bhindi, N. ve Duignan, P. (1997). Leadership for1the new century: Authenticity, intentionality, spirituality and sensibility. Management and Administration Journal, 25(2), 117-132.

Bhindi, N., Smith, R., Hansen, J., ve Riley, D. (2008, April). Authentic leadership in education: a cross-country phenomenon-or, leaders in their own mind. In Enhancing the Heart, Enriching the Mind at the international leadership conference, New Zealand, Vol. 30.

Buchanan, B. (1974). Building organizational commitment: The socialization of managers in work organizations. Administrative Science Quarterly, 19(4), 533-546.

Bozgeyikli, H. (2017). Big five personality traits as the predictor of teachers'organizational psychological capital. Journal of Education and Practice, 8(18), 125-135.

Coşar, S., (2011). Otantik Liderlik kavramı ve ardılları üzerine bir araştırma. Yüksek Lisans Tezi,. Ankara: KHO Savunma Bilimleri Enstitüsü.

Çetin, F. (2011). The effects of the organizational psychological capital on the attitudes of commitment and satisfaction: A public sample in Turkey. European Journal of Social Sciences, 21(3), 373-380.

Çetin, F. ve Basım, H. N. (2011). Psikolojik dayanıklılığın iş tatmini ve örgütsel bağll1ık tutumlarındaki rolü. Endüstri İlişkileri ve İnsan Kaynakları Dergisi, 13(3), 79-94. 
Çınar, E. (2011). Pozitif psikolojinin örgütsel bağlllıkla ilişkisi. Yayınlanmış Yüksek Lisans Tezi, Dokuz Eylül Üniversitesi, Sosyal Bilimler Enstitüsü.

De Hoogh AHB ve Den Hartog DN. (2008). Ethical and despotic leadership, relationships with leader's social responsibility, top management team effectiveness and subordinates' optimism: A multimethod study. The Leadership Quarterly, 19, 297-311.

Doğanay, A. (2014). Liderlik tarzlarının, çalışanların bağlılık seviyesi ve performansina etkisi: Başakşehir Belediyesinde bir uygulama (Master's thesis), İstanbul Gelişim Üniversitesi Sosyal Bilimler Enstitüsü, İstanbul.

Ertürk, Mümin., (2009). İşletmelerde yönetim ve organizasyon. İstanbul: Beta Yayınevi.

Gardner W. L. ve Schermerhorn Jr. (2004). Unleashing individual potential: Performance gains through positive organizational behavior and authentic leadership. Organizational Dynamics, 33(3), 270-279.

Gardner, W. L., Avolio, B. J., Luthans, F., May, D. R., ve Walumbwa, F. (2005). Can you see the real me? A self-based model of authentic leader and follower development. The Leadership Quarterly, 16(3), 343-372.

Grusky, O. (1966). Career mobility and organizational commitment. Administrati and Science Quarterly, 10, 488-503.

Gürbüz, S. ve Şahin, F. (2015). Sosyal bilimlerde araştırma yöntemleri. Ankara: Seçkin Yayınları.

Hall, D. T., Schneider, B., ve Nygren, H. T. (1970). Personal factors in organizational identification. Administrative Quarterly, 15(2), 176190.

Harter, J.K., Schmidt, F.L. ve Hayes, T. L. (2002). Business-unit level relationship between employee satisfaction, employee engagement, and business outcomes: A1 metaanalysis. Journal of Applied Psychology, 87(2), 268-279.

Hrebiniak, L. G. ve Alutto, J. A. (1972). Personal and role-related factors in the development of organizational commitment. Administrative science quarterly, 17(4), 555-573. 
Ilies, R., Morgeson, F.P. ve Nahrgang, J. D. (2005). Authentic leadership and eudaemonic well-being: Understanding leader-follower outcomes. The Leadership Quarterly, 16, 373-394.

Işkın, Y., ve Kaygın, E. (2016). Otantik Liderlik Anlayışının Örgütsel Bağlılık ve Örgütsel Yabancılaşmayla İlişkisi: Mobilya Sektöründe Bir Araştırma. Bartın Üniversitesi İI BF Dergisi, 7(14), 619-647.

Jaworski, B., J. ve Kohli, A. K. (1993). Market Orientation: Antecedents and Consequences. Journal of Marketing, 57(3) , 53-70

Jensen, M. S. ve Luthans, F. (2006). Entrepreneurs as authentic leaders: impact on employees' attitudes. Leadership \& Organization Development Journal, 27(8), 646-666.

Kalaycı, Ş. (2005). SPSS uygulamalı çok değişkenli istatistik teknikleri. İstanbul: Asil Yayın Dağıtım.

Kahn, W. (1990). Psychological Conditions Of Personal. Engagement and Disengagement At Work A. Academy of Management Journal, 33, 692-724.

Kanter, R. M. (1968). Commitment and social organization: A study of commitment mechanisms in utopian communities. American Sociological Review, 33, 499-517.

Karatürk, H. E. (2015). Otantik Liderlik ve Psikolojik Sermaye Arasindaki İlişkiye Yönelik Bir Alan Araştırması. Yüksek Lisans Tezi. Aydın: Adnan Menderes Üniversitesi Sosyal Bilimler Enstitüsü.

Kement, Ü., ve Batga, B. (2016). Mobbing'in Örgütsel Bağl1lı̆ga Etkisi: Eğlence ve İkram Amaçlı Hizmet Veren Rekreasyon İşletmelerinde Bir Araştırma. İşletme Araştırmaları Dergisi, 8(4), 400-420.

Keser, S. (2013). Ilköğretim okulu yöneticilerinin otantik liderlik ve psikolojik sermaye özelliklerinin karşılaştırılması. Yayımlanmamış Yüksek Lisans Tezi, Yıldız Teknik Üniversitesi, Sosyal Bilimler Enstitüsü, İstanbul.

Keser, S. ve Kocabaş, İ. (2014). İlköğretim okulu yöneticilerinin otantik liderlik ve psikolojik sermaye özelliklerinin karşılaştırılması. Kuram ve Uygulamada Eğitim Yönetimi, 20(1), 1-22.

Kernis, M. H. (2003). Toward a conceptualization of optimal self-esteem. Psychological Inquiry, 14(1), 1-26.

Kraut, A. I. (1970). The prediction of turnover by employee attitudes. New York: IBM World Trade Corporation. 
Larson, M. ve Luthans, F. (2006). Potential added value of psychological in predicting work attitudes. Journal of Leadership and Organizational Studies, 13, 44-61.

Laschinger, H. K. S., Finegan, J. ve Wilk, P. (2009). Context matters: The Impact of unit leadership and empowerment on nurses' organizational commitment. Journal of Nursing Administration, 39(5), 228-235.

Luthans, F. (2002a). The need for and meaning of positive organizational behavior. Journal of Organizational Behavior, 23(6), 695-706.

Luthans, F. (2002b). Positive organizational behavior: Developing and managing psychological strengths. Academy of Management Executive, 16, 57-72.

Luthans, F. ve Avolio, B. J. (2003). Authentic leadership: A positive developmental approach. In: K. S. Cameron, J. E. Dutton \& R. E. Quinn (Eds), Positive Organizational Scholarship (pp. 241-261). San Francisco: Barrett-Koehler.

Luthans, F. ve Youssef, C.M. (2004). Human, social, and now positive psychological capital management: Investing in people for competitive advantage. Organizational Dynamics, 33(2), 1-36.

Luthans, F., Avey, J. B., Avolio, B. J., Norman, S. ve Combs, G. M. (2006). Psychological capital development: Toward a micro-intervention. Journal of Organizational Behaviour, 27, 387-393.

Luthans, F., Avey, J. B., Clapp-Smith, R., ve Li, W. (2008). More evidence on the value of Chinese workers' psychological capital: A potentially unlimited competitive resource?. The International Journal of Human Resource Management, 19(5), 818-827.

Luthans, F., Avolio, B. J., Avey, J. B., ve Norman, S. M. (2007a). positive psychological capital: Measurement and relationship with performance and satisfaction. Personnel Psychology, 60(3), 541-572.

Luthans, F., Youssef, C. M. ve Avolio, B. J. (2007b). Psychological Capital: Developing The Human Competitive Edge. Oxford: Oxford University Press.

May, D. R., Chan, A. Y. L., Hodges, T. D. ve Avolio, B. J. (2003). developing the moral component of authentic leadership. Organizational Dynamics, 32, 247-260. 
Meydan, C. H. ve Şeşen, H. (2015). Yapısal eşitlik modellemesi AMOS Uygulamaları. Ankara: Detay Yayınları.

Meyer, J. P. ve Allen, N. J. (1997). Commitment in the workplace. Sage Publications.

Meyer, J.P., Allen, N.J. ve Topolnytsky, L. (1998). Commitment in a changing world of work. Canadian Psychology/Psychologie Canadienne, 39(1-2), 83-93.

Mowday, R. T., Porter, L. W. ve Steers, R. M. (1982). Employeeorganization linkage. the psychology of commitment absenteism, and turn over. Academic Press Inc. London.

Norman, S., Luthans, B. ve Luthans, K. (2005). The proposed contagion effect of hopeful leaders on the resiliency of employees and organizations. Organizational Studies, 12(2), 55-64.

Ocak, M., Güler, M. ve Basim, H. N. (2016). Psikolojik sermayenin örgütsel bağlılık ve iş tatmini tutumları üzerine etkisi: Bosnalı öğretmenler üzerine bir araştırma. Çankırı İktisadi ve İdari Bilimler Fakültesi Dergisi, 6(1), 113-130.

Okun, O. (2017). Psikolojik Sermayenin İş Gören Sesliliğine Etkisinde İyi Olma Halinin Aracı Rolü. Yayımlanmamıs Doktora Tezi. Hasan Kalyoncu Üniversitesi, Sosyal Bilimler Esntitüsü, Gaziantep.

Pittinsky, T. L. ve C. J. Tyson (2005). Leader1authenticity Markers: A Study of African-American Political Leadership. In W. L. Gardner, B.J. Avolio and F. O. Walumbwa (Eds.), Authentic leadership theory and Practice, 3: Origins, effects and development. Elsevier.

Rego, A., Sousa, F., Marques, C., ve Cunha, M.P. (2012). Authentic leadership promoting employees psychological capital and creativity. Journal of Business Research, 65, 429-437.

Rego, P., Lopes, M. P. ve Nascimento, J. L. (2016). Authentic leadership and organizational commitment: the mediating role of positive psychological capital. Journal of Industrial Engineering and Management, 9(1), 129-151.

Salancik, G. R. (1977). Commitment and the control of organizational behavior and belief. InB. M. Staw \& GR Salancik (Eds.), New directions in organizational behavior: 1-54. Chicago: St. 
Savur, N. (2013). Otantik liderlik ve çalışanların psikolojik sermayeleri arasındaki ilişki üzerine bir araştırma. Yayınlanmış Yüksek Lisans Tezi, Afyon Kocatepe Üniversitesi, Sosyal Bilimler Enstitüsü, Afyon.

Saylı, H. ve Baytok, A. (2014). Örgütlerde liderlik teori-uygulama ve yeni perspektifler Ankara: Nobel Yayıncilik.

Sexton, T. (2007). Review of research literature on authentic leadership. England, Creative Edge Consulting Limited

Shamir, B. ve Eilam, G. (2005). What's your story? A life-stories approach to authentic leadership development. The Leadership Quarterly, 16(3), 395-417.

Shao, A. T. (2002). Marketing research. An Aid to Decision Making. Cincinnati.

Sheldon, M. E. (1971). Investments and involvements as mechanisms producing commitment to the organization. Administrative Science Quarterly, 16, 142-150.

Smith, R., Bhindi, N., Hansen, J., Riley, D., ve Rall, J. (2008). Questioning the notion of "authentic" leadership in education: the perspectives of followers. Australian Association for Research in Education (AARE), 5, 2009.

Şeşen, H. (2010). Öncülleri ve Sonuçları İle Örgüt İçi Girişimcilik: Türk Savunma Sanayinde Bir Araştırma. Yayımlanmamış Doktora Tezi, KHO Savunma Bilimleri Enstitüsü, Ankara.

Tabak, A., Polat, M., Coşar, S., ve T., Türköz. (2012). Otantik liderlik ölçeği: güvenirlik ve geçerlik çalışması. The Journal of Industrial Relations \& Human Resources, 14(4), 89-106.

Terzi, A. R. ve Kurt, T. (2005). İlköğretim okulu müdürlerinin yöneticilik davranışlarının öğretmenlerin örgütsel bağlılığına etkisi. Milli Eğitim Dergisi, 33(166), 98-111.

Tugade MM, Fredrickson B.L. ve Barrett LM. (2004). Psychological resilience and positive emotional granularity: Examining the benefits of positive emotions on coping and health. Journal of Personality, 72(6), 1161-1190.

Walumbwa, F. O., Avolio, B. J., Gardner, W. L., Wernsing, T. S. \& Peterson, S. J. (2008). Authentic leadership: Development and validation of a theory-based measure. Journal of Management, 34(1), 89126. 
Yaşbay, H. (2011). Otantik liderlik ve örgütsel bağlllık ilişkisi. Yayımlanmamış Yüksek Lisans Tezi, DEÜ Sosyal Bilimleri Enstitüsü, İzmir.

Youssef, C.M. ve Luthans, F. (2007). Positive organizational behavior in the workplace: The1impact of hope, optimism, and resilience. Journal of Management, 33(5), 774-778.

Yücel, İ. ve Çetinkaya, B. (2015). Örgütsel sinizm ile örgütsel bağlllık arasındaki ilişki ve çalışanların yaşının bu ilişki üzerindeki etkisi“bazen hoşlanmasak da kalmak zorunda olabiliriz!”. Atatürk Üniversitesi Sosyal Bilimler Enstitüsü Dergisi, 19(3), 247-271.

\section{Kaynakça Bilgisi / Citation Information}

Büyükbeşe, T. Çavuşoğlu, S. ve Okun, O. (2019). Otantik liderlik ile örgütsel bağlılık arasında psikolojik sermayenin aracılık rolü: Bingöl üniversitesi örneği. OPUS-Uluslararası Toplum Araştırmaları Dergisi , 10(17), 194-225. DOI: 10.26466/opus.501018 